\title{
Chemical composition of acid lime leaves infected with Candidatus Phytoplasma aurantifolia
}

\author{
Rashid Al-Yahyai ${ }^{{ }^{*}}$, Ali Al-Subhi ${ }^{1}$, Jamal Al-Sabahi ${ }^{2}$, Fahad Al-Said ${ }^{1}$, \\ Khadija Al-Wahaibi ${ }^{1}$, Abdullah M. Al-Sadi ${ }^{1}$ \\ ${ }^{1}$ Department of Crop Sciences, Sultan Qaboos University, Al-Khod, Oman; *Corresponding Author: alyahyai@squ.edu.om \\ ${ }^{2}$ Central Instrumental Laboratory, College of Agricultural and Marine Sciences, Sultan Qaboos University, Muscat, Oman
}

Received 17 September 2013; revised 15 December 2013; accepted 3 January 2014

Copyright (C) 2014 Rashid Al-Yahyai et al. This is an open access article distributed under the Creative Commons Attribution License, which permits unrestricted use, distribution, and reproduction in any medium, provided the original work is properly cited. In accordance of the Creative Commons Attribution License all Copyrights (C) 2014 are reserved for SCIRP and the owner of the intellectual property Rashid Al-Yahyai et al. All Copyright (C) 2014 are guarded by law and by SCIRP as a guardian.

\section{ABSTRACT}

The production of acid lime (Citrus aurantifolia) has declined in many parts of the world due to phytoplasmal infection by "Candidatus Phytoplasma aurantifolia". The resulting Witches' Broom Disease of Lime (WBDL) causes stem and leaf proliferation and clustering that starts on a few branches and continues to spread until trees are killed within 5 - 7 years. Recent studies have shown that Phytoplasma alters the chemical composition of leaves. Leaves from WBDLsymptomatic lime trees were collected to determine their volatile compound composition. Phytoplasmal infection was confirmed by a polymerase chain reaction (PCR) assay using primers P1/P7 and R16F2n/R16R2 in direct and nested PCR, respectively. Restriction fragment length polymorphism (RFLP) profiles of acid lime Phytoplasma were identical with those of WBDL Phytoplasma. The phytochemical composition of symptomatic (infected) and asymptomatic (healthy) leaves of acid lime were determined using GC-MS analysis of steam distilled extract. The WBDL-symptomatic leaves had higher concentration in $\Delta$-limonene, $\beta$-ocimene and trans-caryophyllene and a reduction in other compounds (i.e. citral, citronellal, cisverbenol, neryl acetate, and linalool). Variations in the leaf phytochemical concentration indicate a possible role in the development of the WBDL disease symptoms.

\section{KEYWORDS}

Citrus aurantifolia; Phytoplasma; Essential Oils; Volatile Compounds; Phytochemistry; Oman

\section{INTRODUCTION}

Acid lime (Citrus aurantifolia) has been traditionally cultivated as a major export commodity for decades in South and West Asia, including Oman. The local variety of lime grown in Oman resembles typical Indian, Mexican or Key lime of Florida [1]. In recent years, trees of acid lime in Oman have been seriously affected by witches' broom disease caused by a prokaryotic pathogen, Phytoplasma [2].

Phytoplasmas are wall-less prokaryotes in class Mollicutes. They are gram-positive, mainly restricted to the phloem and are non-culturable and associated with various diseases in several hundred plant species from over one hundred plant families, including many citrus species [3-5]. Molecular methods based on sequences and RFLP analysis of PCR amplified 16S rDNA gene sequences are used for detection and classification of Phytoplasmas such as Witches' Broom Disease of Lime (WBDL) [6,7]. Symptoms typical of Phytoplasma in lime, including leaf and stem proliferation and clustering (Figure 1), were first reported in Oman in the 1970's [8]. Bove [2,9] identified Phytoplasma as the causal agent of WBDL. Zreik et al. [10] classified the WBDL Phytoplasma to sunhemp phyllody Phytoplasma and named it "Candidatus Phytoplasma aurantifolia" according to sequences of the 16S rRNA gene. In Oman, WBDL Phytoplasma infected $98 \%$ of mature lime trees resulting in the devastation of one of the few important export commodities in the country and is threatening lime production in neighboring countries [11].

Essential oils are complex mixtures of volatile organic compounds produced as secondary metabolites in plants, not essential for plant growth and development [12], and composed of hydrocarbons and oxygenated compounds [13]. Certain plant secondary metabolic pathways are induced in response to abiotic or biotic stresses including 


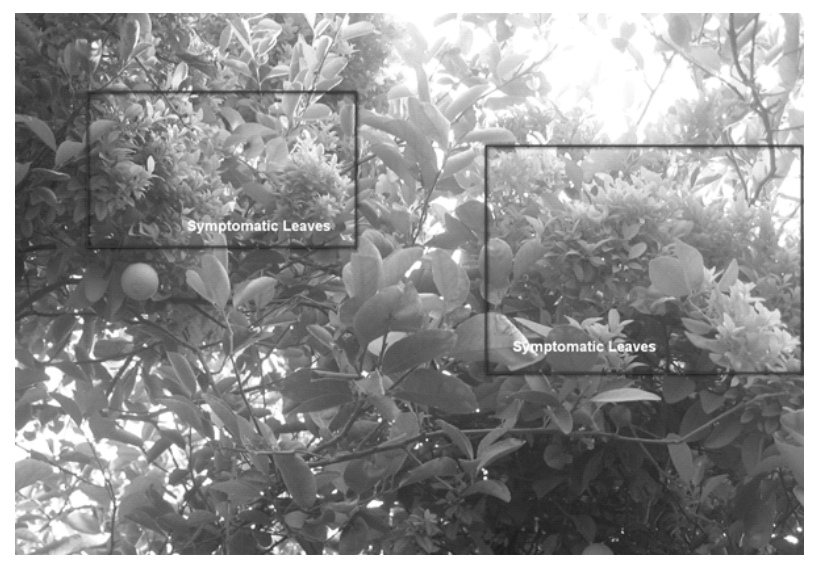

Figure 1. WBDL-infected acid lime trees showing symptomatic (within rectangles) and asymptomatic leaves.

pathogens, such as Phytoplasma infection, and thus a pathway might increase or decrease the concentration of metabolites in infected plants [14]. The metabolic responses to pathogenic infection have received greater attention in recent years. Phytoplasma-infected Hypericum perforatum L. showed a decrease in total flavonoids and pseudohypericin content, whereas the amount of chlorogenic acid increased significantly [15]. Phytoplasma-infected Monarda fistulosa had higher levels of monoterpenes and $\alpha$-caryophyllene but lower thymol compared to the symptompless plants [16]. The presence of such compounds in various concentrations may ameliorate the effects of the disease and prolong the productive life of the plant [17]. We hypothesize that leaf phytochemical composition may play a role in the proliferation of symptoms in infected citrus trees. The objective of this study was to examine the effect of Phytoplasmal infection on the level of volatiles compounds of acid lime.

\section{MATERIALS AND METHODS}

\subsection{Phytoplasma Identification}

Leaf samples of 6-years old acid lime were collected from infected plants showing witches' broom disease (WBDL) symptoms and from asymptomatic lime plants grown in another orchard and used for molecular analysis and phytochemical determination. The samples were collected from trees grown at the Agricultural Experiment Station of Sultan Qaboos University (SQU), Oman. Total nucleic acid was extracted from asymptomatic and symptomatic leaves using the cetyltrimethylammoniumbromide (CTAB) method with modifications [18]. A PCR using primer pair P1/P7 [(5'-CGGAAACCTTCGGGTTTTAG-3’)/(5'-CGTCCTTCATCGGCTCTT-3')] [19,20], as a direct amplification followed by R16F2n/R2 [7] as a nested amplification was performed to detect Phytoplasmas from acid lime trees. The PCR products from the direct step were digested individually with each of the restriction enzymes Tru9I, HaeIII, HpaII, AluI, TaqI, HhaI, and RsaI according to the manufacturers' instructions. The resulting RFLP patterns were compared with those of the alfalfa and lime witches' broom Phytoplasma from Oman [10,21].

\subsection{Gas Chromatography-Mass Spectrometry (GC-MS) Analyses}

Symptomatic and asymptomatic fresh leaf samples of Phytoplasma-infected lime were collected from the acid lime trees mentioned above in October 2010. Representative leaves were collected from branches located in the middle of the tree that are facing southward. Fresh (300 g) asymptomatic and symptomatic leaves were steam-distilled for 5 hours using a Clevenger-type apparatus to extract essential oil [22].

GC-MS analysis of the extracted oil was performed on a Perkin Elmer Clarus 600 GC System, fitted with a HP-5MS capillary column $(30 \mathrm{~m} \times 0.25 \mathrm{~mm}$ i.d. $\times 0.25$ $\mu \mathrm{m}$ film thickness; maximum temperature, $350^{\circ} \mathrm{C}$ ), coupled to a Perkin Elmer Clarus 600C MS. Ultra-high purity helium (99.9999\%) was used as carrier gas at a constant flow of $1.0 \mathrm{ml} / \mathrm{min}$. The injection, transfer line and ion source temperatures were $290^{\circ} \mathrm{C}, 250^{\circ} \mathrm{C}$ and $200^{\circ} \mathrm{C}$, respectively. The ionizing energy was $70 \mathrm{eV}$. Electron multiplier (EM) voltage was obtained from autotune. All data were obtained by collecting the full-scan mass spectra within the scan range 40 - 550 amu. The injected sample volume was $1 \mu \mathrm{l}$ with a split ratio of $1: 150$. The oven temperature program was $60^{\circ} \mathrm{C}$ at a rate of $3^{\circ} \mathrm{C} / \mathrm{min}-280^{\circ} \mathrm{C}$ hold for 2 minutes. The unknown compounds were identified by comparing the spectra obtained with mass spectrum libraries (NIST 2005 v.2.0 and Wiley Access Pak v.7, 2003) and the results were confirmed by calculating the retention indices.

\section{RESULTS AND DISCUSSION}

The symptomatic and asymptomatic lime samples were used for the detection of Phytoplasma by PCR assays. A product of $1.8 \mathrm{~kb}$ was consistently amplified by PCR using P1/P7 primers from infected samples. Nested PCR amplification using R16F2n/R16R2 primers yielded $1.2 \mathrm{~kb}$ fragment when direct PCR amplified DNA was used as template. No amplification was obtained from asymptomatic lime samples and water samples by direct or nested PCR. RFLP analyses of direct PCR products with Tru9I, HaeIII, HpaII, AluI, TaqI, HhaI, and RsaI endonucleases yielded patterns typical of lime witches' broom Phytoplasma.

Twenty one phytochemical compounds were included in this study (Table 1). The compounds which showed more than $0.05 \%$ concentration after GC-MS analysis of steam distilled extract were included. Analysis of the chemical constituents of the infected acid lime leaves 
Table 1. Phytochemical compounds composition of samples from WBDL-symptomatic and asymptomatic acid lime.

\begin{tabular}{|c|c|c|c|}
\hline \multirow{2}{*}{ Compounds } & \multicolumn{3}{|c|}{${ }^{\mathrm{a}} \mathrm{RA} \%$} \\
\hline & KI & Symptomatic & Asymptomatic \\
\hline$\Delta$-limonene & 1042.195 & 56.14 & 24.028 \\
\hline e-citral & 1282.311 & 16.728 & 27.807 \\
\hline z-citral & 1253.365 & 10.808 & 24.411 \\
\hline$\beta$-ocimene & 1054.569 & 3.463 & 2.304 \\
\hline geranyl acetate & 1394.645 & 3.148 & 4.129 \\
\hline trans-caryophyllene & 1423.42 & 1.828 & 0.853 \\
\hline citronellal & 1158.598 & 0.998 & 2.405 \\
\hline cis-geraniol (nerol) & 1266.477 & 0.887 & 0.33 \\
\hline cis-verbenol & 1189.256 & 0.759 & 1.738 \\
\hline$\beta$-myrcene & 995.929 & 0.67 & 0.434 \\
\hline cis-verbenol & 1170.595 & 0.516 & 0.972 \\
\hline neryl acetate & 1372.68 & 0.489 & 1.056 \\
\hline geraniol & 1268.209 & 0.454 & 0.998 \\
\hline cis-ocimene & 1044.099 & 0.443 & 0.398 \\
\hline germacrene & 1559.359 & 0.359 & 0.484 \\
\hline linalool & 1105.812 & 0.266 & 1.534 \\
\hline nerol & 1238.768 & 0.176 & 0.361 \\
\hline $2 \beta$-pinene & 980.1 & 0.014 & 0.017 \\
\hline nerolidol & 1570.214 & 0.009 & 0.022 \\
\hline p-vinylguacial & 1321.594 & 0.005 & 0.133 \\
\hline 2-hexen-l-al & 855.462 & 0 & 0.065 \\
\hline
\end{tabular}

${ }^{\mathrm{a}} \mathrm{RA} \%$, relative area percentage.

showed distinct differences in concentrations compared to healthy acid lime leaves (Figure 2). Studies have shown that plant pathogens affect the amount and composition of phytochemicals, mainly the essential oils, of the host plant resulting in alteration of plant secondary metabolism [15,23,24].

The increase in certain compounds in WBDL-symptomatic leaves (i.e. $\Delta$-Limonene, $\beta$-ocimene and transcaryophyllene) and the reduction in other compounds (i.e. $e$-citral, $z$-citral, citronellal, cis-verbenol, neryl acetate, and linalool) are related to Phytoplasma infection and the interaction between host and pathogen [25]. It is possible that the observed changes were a result of acid lime responses to Phytoplasma infection [24]. In our study, citrus essential oil of infected (I) leaves showed the highest concentration of $\Delta$-limonene (56.140\%) compared to healthy $(\mathrm{H})$ leaves $(24.028 \%)$. Other compounds that

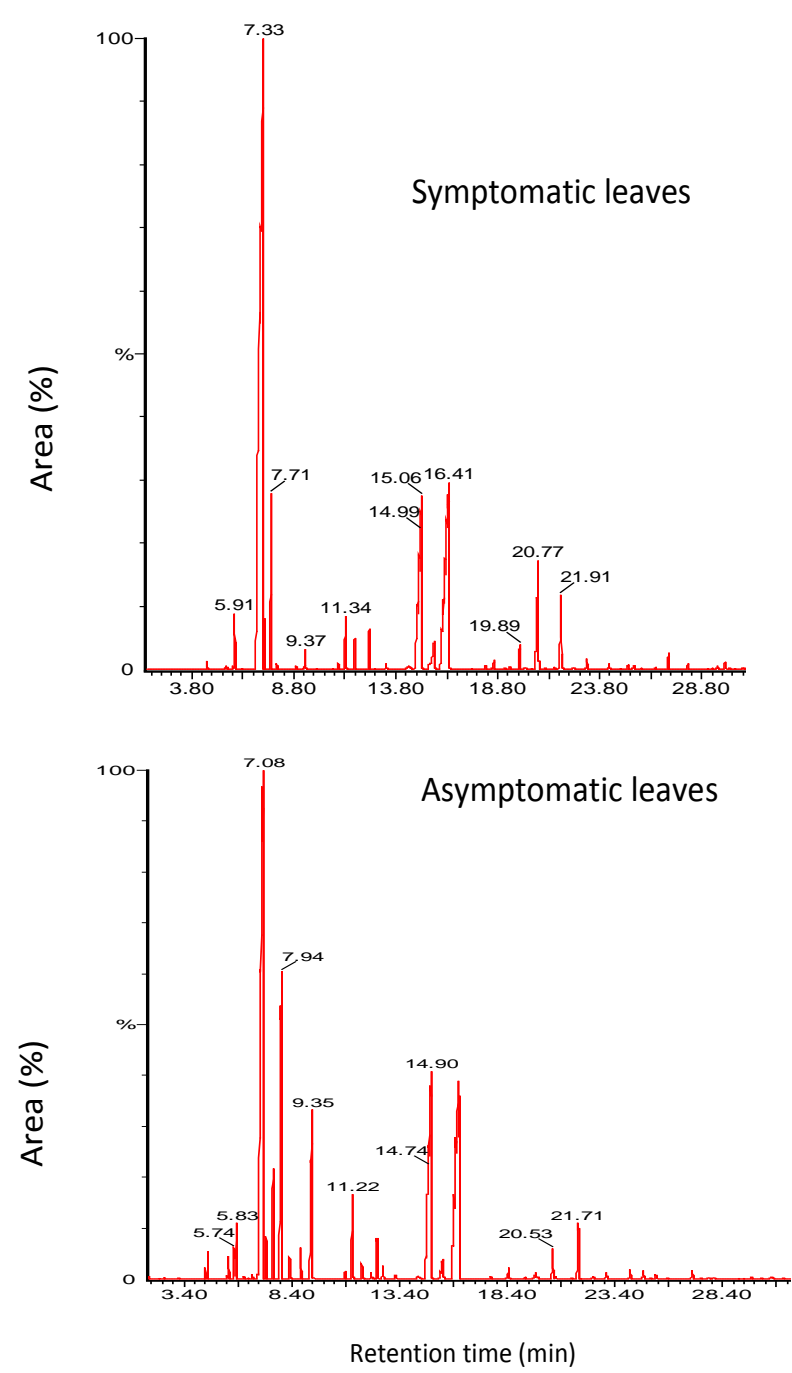

Figure 2. Chromatograms of symptomatic and asymptomatic leaves of Omani lime infected with WBDL.

increased in infected leaves were $\beta$-ocimene ( $\mathrm{I}=3.463 \%$, $\mathrm{H}=2.304 \%)$, trans-caryophyllene $(\mathrm{I}=1.828 \%, \mathrm{H}=$ $0.853 \%)$, cis-geraniol (Nerol) $(\mathrm{I}=0.887 \%, \mathrm{H}=0.330 \%)$, and $\beta$-myrcene ( $\mathrm{I}=0.670 \%, \mathrm{H}=0.434 \%$ ). Phytoplasma infection is known to change the cell metabolism leading to an increase of certain compounds and the reduction of others [4,25-27].

Most of other compounds were higher in healthy trees and lower in infected trees, primarily $e$-citral $(\mathrm{I}=$ $16.728 \%, \mathrm{H}=27.807 \%)$ and $z$-citral $(\mathrm{I}=10.808 \%, \mathrm{H}=$ $24.411 \%)$. Citral ameliorates the effects of bacterial and phytoplasmal infection in several plants, including coconut and maple. Other compounds were also reduced but at a smaller scale, including geranyl acetate ( $\mathrm{I}=$ $3.148 \%, \mathrm{H}=4.129 \%$ ), which was present in moderate quantities in all samples. Citronellal, cis-verbenol, neryl acetate, and linalool were present in symptomatic leaves at lower concentration $[25,28]$. 
We hypothesize that leaf essential oil composition plays a role in the proliferation of symptoms in infected acid lime trees. Our results showed variations in the chemical composition of acid lime leaves between symptomatic and asymptomatic leaves. This may indicate a possible role of these chemicals on the susceptibility and severity of WBDL disease. Understanding the interaction between the pathogen (Phytoplasma) and the host (acid lime), specifically in altering leaf phytochemical composition, is essential to predict the time of disease symptom expression and post-infection tree productive life. Further studies are needed to determine the evolution of pathogen infection and the role of phytochemicals in WBDL symptom development.

\section{ACKNOWLEDGEMENTS}

Authors would like to acknowledge Prof. Michael Deadman for his critical comments on the first draft of this manuscript. We acknowledge Sultan Qaboos University for funding this study through the Strategic Research Project: Rejuvenating lime production in Oman: resolving current challenges (SR/AGR/CROP/08/01).

\section{REFERENCES}

[1] Hodgson, R.W. (1967) Horticultural varieties of citrus. In: Reuther, W., Webber, H.J. and Batchelor, L.D. Eds. The Citrus Industry, Vol. I. University of California Press, Berkeley, 431-592.

[2] Bové, J.M. (1986) Witches' broom of lime. FAO Plant Protection Bulletin, 34, 217-218.

[3] Hogenhout, S.A., Oshima, K., Ammar, E.D., Kakizawa, S., Kingdom, H.N. and Namba, S. (2008) Phytoplasmas: Bacteria that manipulate plants and insects. Molecular Plant Pathology, 9, 403-423. http://dx.doi.org/10.1111/j.1364-3703.2008.00472.x

[4] Lee, I.M., Davis, R.E. and Gundersen-Rindahl, D.E. (2000) Phytoplasma: Phytopathogenic mollicutes. Annual Review of Microbiology, 54, 221-255. http://dx.doi.org/10.1146/annurev.micro.54.1.221

[5] Bove, J.M. and Garnier, M. (2000) Witches' broom disease of lime. Arab Journal of Plant Protection, 18, 148152.

[6] Firrao, G., Gibb, K. and Streten, C. (2005) Short taxonomic guide to the genus "Candidatus Phytoplasma". Journal of Plant Pathology, 87, 249-263.

[7] Gundersen, D.E. and Lee, I.M. (1996) Ultrasensitive detection of Phytoplasmas by nested-PCR assays using two universal primer pairs. Phytopathologia Mediterranea, 35, 114-151.

[8] Waller J.M. and Bridge J. (1978) Plant diseases and nematodes in the Sultanate of Oman. Pest Articles and News Summaries (PANS), 24, 313-326.

[9] Bove, J.M., Garnier, M., Mjeni, A.M. and Khayrallah, A. (1988) Witches' broom disease of small fruited acid lime trees in Oman: First MLO disease of citrus. Proceedings of the International Organization for Citrus Virologists, 10, 307-309.

[10] Zreik, L., Carle, P., Bove, J.M. and Garnier, M. (1995) Characterization of the mycoplasma-like organism associated with witches' broom disease of lime and proposition of a Candidatus taxon for the organism "Candidatus Phytoplasma aurantifolia”. International Journal of Systematic Bacteriology, 45, 449-453. http://dx.doi.org/10.1099/00207713-45-3-449

[11] Al-Sadi, A.M., Al-Moqbali, H.S., Al-Yahyai, R.A. and Al-Said, F.A. (2012) AFLP data suggest a potential role for the low genetic diversity of acid lime (Citrus aurantifolia Swingle) in Oman in the outbreak of witches' broom disease of lime. Euphytica, 188, 285-297. http://dx.doi.org/10.1007/s10681-012-0728-7

[12] Yuan, Z.L., Dai, C.C. and Chen, L.Q. (2007) Regulation and accumulation of secondary metabolites in plant-fungus symbiotic system. African Journal Biotechnology, 6, 1266-1271.

[13] Guenther, E. (1972) The essential oils. Krieger Publishing Company, New York, 453-454.

[14] Fischbach, M.A. and Clardy, J. (2007) One pathway, many products. Nature Chemical Biology, 3, 353-355. http://dx.doi.org/10.1038/nchembio0707-353

[15] Bruni, R., Pellati, F., Bellardi, G.M., Paltrinieri, S., Bertaccini, A. and Bianchi, A. (2005) Herbal drug quality and phytochemical composition of Hypericum perforatum L. affected by ash yellows Phytoplasma infection. Journal of Agricultural and Food Chemistry, 53, 964-968. http://dx.doi.org/10.1021/jf0487654

[16] Contaldo, N., Bellardi M.G., Cavicchi L., Epifano F., Genovese S., Curini M. and Bertaccini A. (2011) Phytochemical effects of Phytoplasma infections on essential oil of Monarda fistulosa L. Bulletin of Insectology, 64, S177-S178.

[17] Nerio, L.S., Olivero-Verbel, J. and Stashenko, E. (2010) Repellent activity of essential oils: A review. Bioresource Technology, 101, 372-378. http://dx.doi.org/10.1016/j.biortech.2009.07.048

[18] Saghai-Maroof, M.A., Soliman, K.M., Jorgensen, R.A. and Allard, R.W. (1984) Ribosomal DNA spacer-length polymorphisms in barley: Mendelian inheritance, chromosomal location, and population dynamics. Proceedings of the National Academy of Sconce (USA), 81, 8014-8018. http://dx.doi.org/10.1073/pnas.81.24.8014

[19] Deng, S.J. and Hiruki, C. (1991) Genetic relatedness between two non-culturable mycoplasma-like organisms revealed by nucleic acid hybridization and polymerase chain reaction. Phytopathology, 81, 1475-1479. http://dx.doi.org/10.1094/Phyto-81-1475

[20] Schneider, B., Seemüller, E., Smart, C.D. and Kirkpatrick, B.C. (1995) Phylogenetic classification of plant pathogenic mycoplasma-like organisms or Phytoplasmas. In: Razin, S. and Tully, J.G. Eds., Molecular and Diagnostic Procedures in Mycoplasmology, Vol. I. Academic Press, San Diego, 369-380. http://dx.doi.org/10.1016/B978-012583805-4/50040-6

[21] Khan, A.J., Botti, S., Al-Subhi, A.M., Gundersen-Rindal, 
D.E. and Bertaccini, A.F. (2002) Molecular identification of a new Phytoplasma associated with alfalfa witches' broom in Oman. Phytopathology, 92, 1038-1047. http://dx.doi.org/10.1094/PHYTO.2002.92.10.1038

[22] Jazet Dongmo, P.M., Tatsadjieu, L.N., Tchinda Sonwa, E., Kuate, J., Amvam Zollo, P.H. and Menut, C. (2009) Essential oils of Citrus aurantifolia from Cameroon and their antifungal activity against Phaeoramularia angolensis. African Journal of Agricultural Research, 4, 354358. http://dx.doi.org/10.1080/10412905.2002.9699911

[23] Hudaib, M., Cavrini, V., Bellardi, M.G. and Rubies-Autonell, C. (2002) Characterization of the essential oil of healthy and virus infected Echinacea purpurea (L.) Moench plants. Journal of Essential Oil Research, 14, 427430.

[24] Mazid, M., Khan, T.A. and Mohammad, F. (2011) Role of secondary metabolites in defense mechanisms of plants. Biology \& Medicine, 3, 232-249.

[25] Bertaccini, A., Contaldo, N., Benni, A., Curini, M., Genovese, S., Epifano, F. and Bellardi, M.G. (2011) Effetcs of "Candidatus Phytoplasma asteris" on the volatile chemical content and composition of Grindelia robusta Nutt. Journal of Phytopathology, 159, 124-126.
http://dx.doi.org/10.1111/j.1439-0434.2010.01727.X

[26] Choi, Y.H., Tapias, E.C., Kim, H.K., Lefeber, A.W.M., Erkelens, C., Verhoeven, J.T.J., Brzin, J., Zel, J. and Verpoorte, R. (2004) Metabolic discrimination of Catharanthus roseus leaves infected by Phytoplasma using $1 \mathrm{H}$ NMR spectroscopy and multivariate data analysis1. Plant Physiology, 135, 2398-2410. http://dx.doi.org/10.1104/pp.104.041012

[27] Pellati, F., Epifano, F., Contaldo, N., Orlandini, G., Cavicchi, L., Genovese, S., Bertelli, D., Benvenuti, S., Curini, M., Bertaccini, A. and Bellardi, G.M. (2011) Chromatographic methods for metabolite profiling of virusand Phytoplasma-infected plants of Echinacea purpurea. Journal of Agriculture and Food Chemistry, 59, 1042510434. http://dx.doi.org/10.1021/jf2025677

[28] Pellati, F., Bruni, R., Bellardi, M.G., Bertaccini, A. and Benvenuti, S. (2009) Optimization and validation of a high performance liquid chromatography method for the analysis of cardiac glycosides in Digitalis lanata. Journal of Chromatography A, 1216, 3260-3269. http://dx.doi.org/10.1016/j.chroma.2009.02.042 